\title{
Botryoid-Type Embryonal Rhabdomyosarcoma of the Vagina
}

National Cancer Institute

\section{Source}

National Cancer Institute. Botryoid-Type Embryonal Rhabdomyosarcoma of the Vagina.

NCl Thesaurus. Code C40268.

A morphologic variant of embryonal rhabdomyosarcoma arising from the vagina. It is characterized by the formation of a cambium layer in the affected tissue and polypoid nodules within an abundant myxoid stroma. 